\title{
Are Bond Defaults with the Connivance of Credit Rating: An Analysis of China's Bond Market
}

\author{
Xudong Zhuang1, Yu Wu² \\ ${ }^{1}$ School of Economics and Finance, South China University of Technology, Guangzhou, China \\ ${ }^{2}$ School of Interpreting and Translation Studies, Guangdong University of Foreign Studies, Guangzhou, China \\ Email: xudongfinance@163.com
}

How to cite this paper: Zhuang, X. D., \& $\mathrm{Wu}, \mathrm{Y}$. (2021). Are Bond Defaults with the Connivance of Credit Rating: An Analysis of China's Bond Market. Open Journal of Business and Management, 9, 2171-2182. https://doi.org/10.4236/ojbm.2021.95115

Received: July 28, 2021

Accepted: August 27, 2021

Published: August 30, 2021

Copyright ( 2021 by author(s) and Scientific Research Publishing Inc. This work is licensed under the Creative Commons Attribution International License (CC BY 4.0).

http://creativecommons.org/licenses/by/4.0/ (c) (i) Open Access

\begin{abstract}
We find that there is a same tendency between credit ratings and bond defaults by analyzing the status quo of defaults in Chinese market and credit ratings from 2015 to 2020 . Caused by the interest conflicts of business models, ancillary business, public information ratings and horizontal competition, the quality of credit rating is badly impacted, thus resulting in the defaults. Therefore, we explain the reasons for such a tendency from interest conflict perspectives. We also offer some proposals to avoid default problems and improve the ratings provided by credit rating agencies, so as to promote the healthy development of bond market and preventing the systemic risks that bond market brings. Consequently, our study systematically concludes the interest conflict problems that lead to rating inflation and enriches related literature.
\end{abstract}

\section{Keywords}

Credit Rating, Bond Default, Conflict of Interest, Financial Supervision

\section{Introduction}

China's bond defaults are increasingly prevalent in recent years and the amount of defaulted debts is rising at the same time. It has surged from 1.34 billion yuan of the first bond default in 2014 to 122.898 billion yuan in 2020. What's more, the types of bond defaulters are becoming various, ranging from private-owned to central government owned and state-owned enterprises. The financial risk is ramping up and it poses a threat to the healthy development of the China's financial market and stability of the macroeconomy. 
In order to wrestle with the bond defaults and build the confidence of investors, it is of vital importance to construct a good credit rating system to assess and reduce the financial risks. Credit rating evaluates the probabilities of the defaults of the borrowing entity and plays a significant role in sustaining equity and stability of the capital market. With proper and accurate credit rating mitigating the debtors defaulting, the steady financial and national economic development are ensured and guaranteed.

In China, credit rating industry is freshly emerging in recent decades and making some progress. These years have witnessed the government's efforts to facilitate the development of the bond market and credit rating industry and prevent the financial systemic risks. China has adopted numerous guiding policies and improved related regulation. The People's Bank of China, National Development and Reform Commission, Ministry of Finance and China Securities Regulatory Commission issued an interim regulation for the credit rating industry on Nov $26^{\text {th }}, 2019$ to improve the financing environment and prevent financial risks. The measures will help construct a competitive market in the industry and strengthen the supervision of credit rating agencies (CRAs). Besides, to standardize the industry, the amount of penalties for violations was increased. However, China's bond credit rating has still received a barrage of criticism. In contrast to developed countries, the industry does not have unified regulation, good business reputation and independence (that is corruption, the conflicts of interests etc.). As an indispensable part of bond pricing and regulation, the flawed credit rating is a cause for massive faulted bonds and the rating is urged to be improved and standardized.

Therefore, we pay more emphasis on the relationship between the credit rating and bond defaults, hoping to provide a insight of measures for preventing the bond defaults: by improving the quality of the credit rating.

\section{Literature Review}

Currently, there is a relative paucity of studies investigating the bond defaults and the existing literature does not reach an agreement on what the factors impacting on bond defaults are and what the future intervention should be. The previous experience shows that the corporate financial crisis is prone to result in massive bond defaults and it is closely related to the macroeconomy (Giesecke et al., 2011). In the period of economic upturn, there is little likelihood for enterprises defaulting while in economic downturn; the risk is increased (Kuehn \& Schmid, 2014). In times of industry-wide distress, there are greater chances for firms to fail to make their payments (Acharya et al., 2007). Besides, government's implicit guarantee is also a factor resulting in the prevailing of bond defaulting (Wang et al., 2016).

Credit rating, justified as an effective standard of credit, is utilized to assess the credit quality of a borrower and help make judgements. It is based on information provided by the prospective debtor and other non-public information 
(Ghosh \& Moon, 2005). According to a study conducted by Kisgen (2006), CRAs provide information on the company credibility beyond the public information, thus gaining more advantages and priority over investors in terms of the acquisition of information. They are available to more comprehensive information and the credit rating helps circulate useful information about firms in the market. Therefore, the informational asymmetry between the firms and investors can be rectified and the risk of bond defaulting is also lower (Millon \& Thakor, 1985). However, some scholars hold that there is heterogeneity among different CRAs. Different CRAs offer different rating standards. Their credibility and influence are also divergent ( $\mathrm{Li}$ et al., 2006). In China, CRAs' rating scales vary from those of international credit rating agencies (Livingston et al., 2018). Besides, CRAs also pursue the increase of market shares and tend to offer positively biased rating (Poon \& Chan, 2008). Scholars also find out that there is an increase of informativeness and decrease of ratings in China CRAs after the enter of China Bond Rating, an independent CRA (Hu et al., 2019). Consequently, the quality of credit rating can influence the investors' decisions and can play a pivotal role in defaulting.

There are also some scholars investigating the relationship between credit rating and bond defaults. Relevant literature explores more from the perspective of analyzing the factors that affect credit rating, trying to demonstrate that credit rating does not reflect the quality of bonds well, which stimulates the defaulting behavior. For example, the work experience of credit analysts would impact on the credit quality they score (Cornaggia et al., 2016). Failing to identify the earnings management leads to the less accurate credit ratings (Ma \& Shi, 2016). The collusion between CRAs and firms rated can also result in the failing in regulation of the credit rating quality (Stolper, 2009). They indirectly cause defaults. However, the function of credit rating cannot be denied and the credit rating change has a certain impact on the market (Finnerty et al., 2013). It facilitates the constraints on the happening of defaults. Related studies find out that crediting rating is of vital importance to the information transparency and healthy development in bond market (Boot et al., 2006; Sufi, 2007; Bosch \& Steffen, 2011).

To conclude, the relationship between bond defaults and credit rating is still open to discussion. The extant literature fails to offer precise theoretical framework and analysis of their relationship based on the perspective of interest conflicts. Therefore, we analyze the status quo of the bond defaults and credit rating in China from 2015 to 2020. We find out that there is a same tendency between the credit rating inflation and bond defaults, meaning that the credit rating cannot reflect the genuine quality of bonds. By focusing on the interest conflicts of the different business models, subsidiary business, public information rating and horizontal competition, we explain why there is a contradiction between the inflated rating and defaults. We also propose some suggestions to restrain the bond defaults from the view of credit rating. 


\section{The Analysis of Defaults in China's Bond Market}

The first bond default emerged in 2014 and the situation has become more severe with years passing by since 2015 . Therefore, we utilize the defaults in China's bond market from 2015 to 2020 as our research sample to analyze the status quo of China's bond defaults and credit rating based on the scientificalness and availability of the data. The statistics of related bond defaults come from Wind Economic Database. Wind is a leading company in China's financial information services industry and its database offers one of the most comprehensive and complete information on Chinese bond. Therefore, the authority and reliability of the statistics can be ensured.

\subsection{Analysis of Defaults in the Bond Market}

In recent years, China's bond defaults are becoming increasingly severe. There were 6 bond defaults in 2014, which began surging after 2014 and there were 145 in 2019. In 2020, in order to take measures against the pandemic, Chinese government offered adequate liquidity assistance to the bond market in different phases of the pandemic and economic recovery. Due to the relatively loose financing environment in the bond market, the default problem was improved. However, the amount of a single defaulted bond was large so the default amount increased instead, totaling 122.898 billion yuan, climbing $14.53 \%$ year-on-year. Regarding to the increase of defaulted entities, the growth in number from 2018 to 2020 maintains in a high level, respectively 43, 39 and 32. From 2018 to 2020, compensation balance of the freshly emerging defaulters is up to 141.368, 115.846 and 215.197 billion yuan respectively. In conclusion, China's bond defaults are prevalent and there is an urge to mitigate the defaulting problem.

\subsection{Analysis of the Same Tendency between Credit Ratings and Bond Defaults}

Default in credit rating refers to the fact that the debtor fails to repay the principal and interest of the debt as agreed in the contract. The definition of credit rating and default is consistent with the CRAs. We also count in the issuers who pay in time by the guarantee or collateral disposition as defaulters. The statistics in our study include the issuers of short-term financing bonds, super short-term commercial papers, medium-term notes, corporate bonds, corporate bonds, convertible bonds, collective commercial papers, and corporate joint bonds ${ }^{1}$, excluding non-financial bond issuers such as local government bonds, private placement notes, asset-backed securities, and privately raised company bonds.

Figure 1 and Figure 2 present the credit ratings of defaulted bonds at the beginning of the given year. Their credit ratings mainly focus on AA from 2015 to 2020 , accounting for $57.89 \%$ and for the largest proportion. Besides, $72.18 \%$ of defaulters are the rank AAA, AA and A. Figures 3-5 illustrate that in the recent ${ }^{1}$ Collective commercial papers and corporate joint bonds are guaranteed by at least two issuers. All issuers are counted in the statistics. 


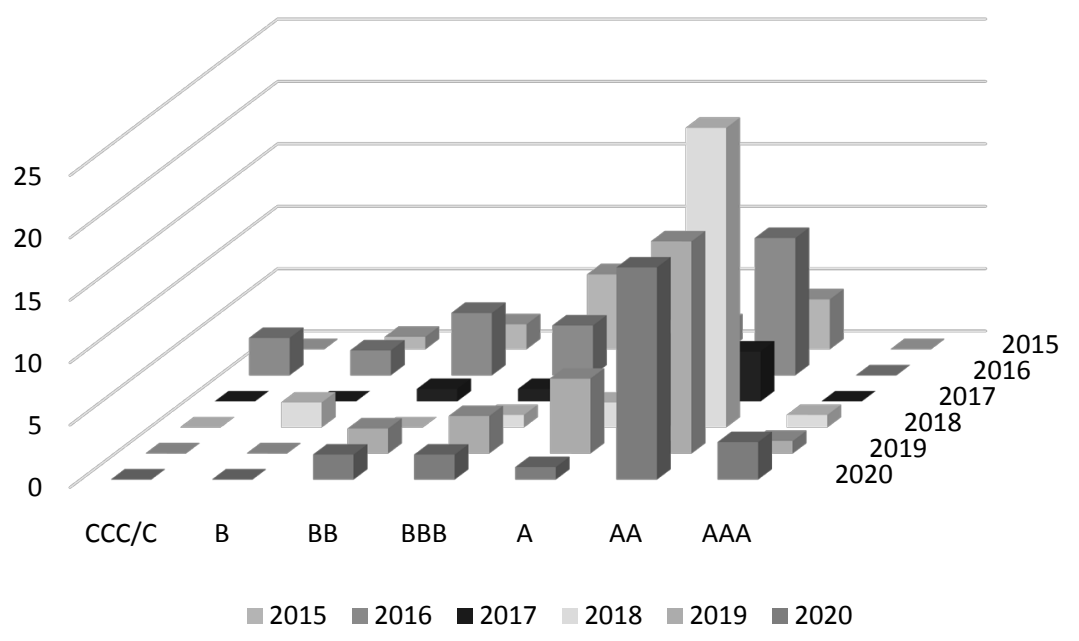

Figure 1. Credit ratings of defaulters at the beginning of the given year (2015-2020).

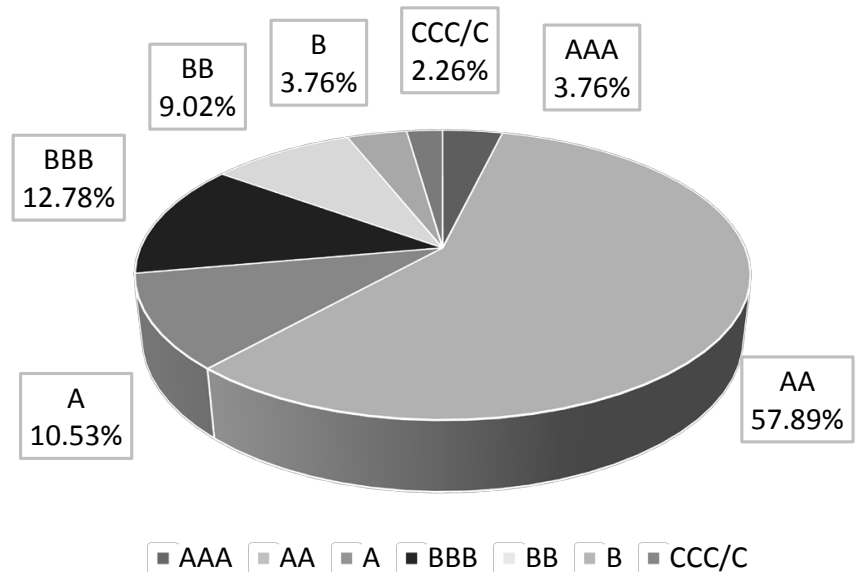

Figure 2. Percentage of credit ratings of defaulters at the beginning of the given year (2015-2020).

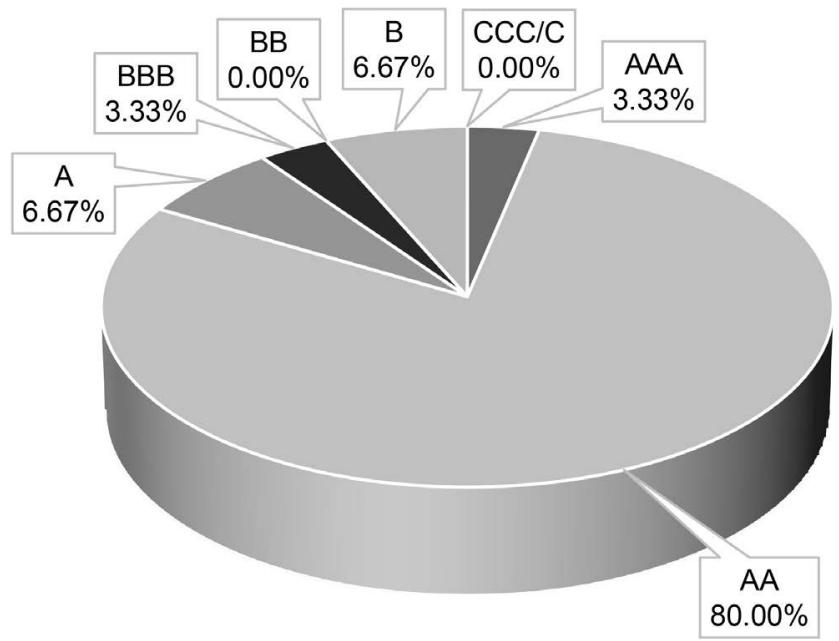

- $\mathrm{AAA}=\mathrm{AA}\|\mathrm{A}\| \mathrm{BBB}=\mathrm{BB}\|\mathrm{B}\| \mathrm{CCC} / \mathrm{C}$

Figure 3. Percentage of credit ratings of defaulters at the beginning of 2018. 


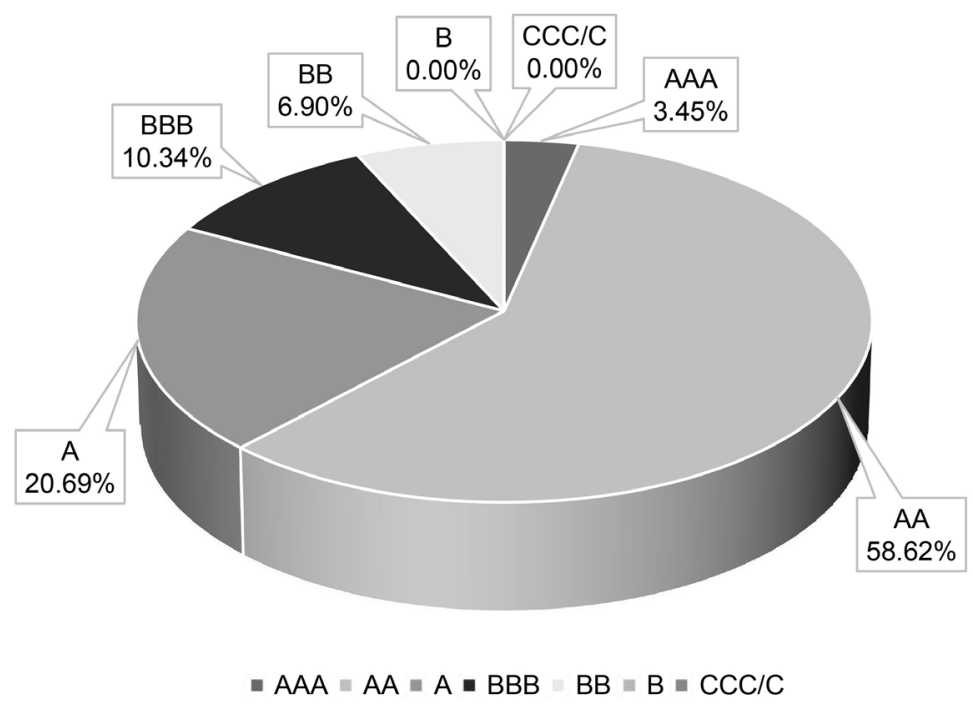

Figure 4. Percentage of credit ratings of defaulters at the beginning of 2019.

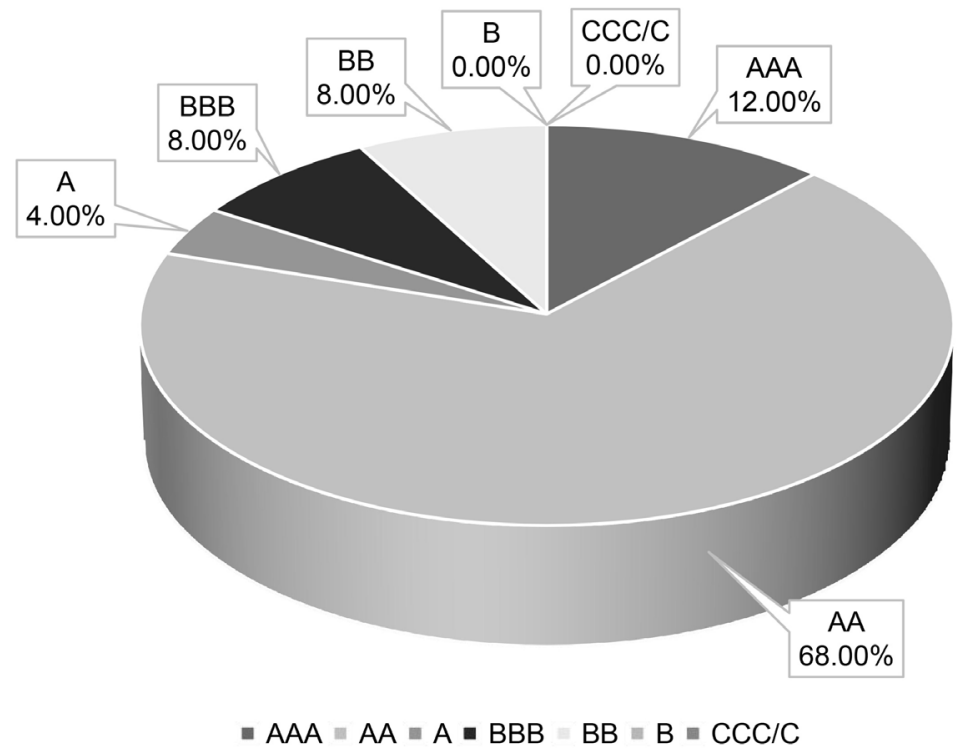

Figure 5. Percentage of credit ratings of defaulters at the beginning of 2020.

3 years the percentage of AA-rank firms is still relatively high and the percentage is respectively $80.00 \%, 58.62 \%$ and $68.00 \%$. The proportion of the defaulting entities with AAA, AA and A ratings to all the defaulters is $90.00 \%^{2}, 82.76 \%$ and $84.00 \%$ respectively in these three years. In a nutshell, there is a same tendency between credit ratings and bond defaults, which means that the higher credit ratings imply higher risks. Due to some sorts of reasons, the credit ratings cannot objectively reflect the quality of bonds, thus resulting in high probability of bond defaults. Therefore, focusing on the defaulting problem in China's bond market, we analyze the reason for the same tendency between credit ratings and bond defaults from the perspectives of the interest conflicts and the intimate ${ }^{2}$ It is the sum of the proportion of defaulters with AAA, AA and A ratings. The following is the same. 
connection between the credit ratings and defaults. It is very crucial to avoid bond defaults from the view of credit ratings.

\section{The Analysis of the Cause for the Same Tendency}

Basing on the current situation in China's credit rating industry, we analyze the reason for the same tendency between credit ratings and bond defaults. Interest conflicts denote a phenomenon in professional service area. Generally, they are the conflicts of different stakeholders. Due to the specific characteristics and standards of the credit rating industry, they bring the problem of interest conflicts among different business models, subsidiary business, public information rating and horizontal competition, influencing the quality of the credit ratings and indirectly leading to the massive bond defaults.

\subsection{The Interest Conflict of Business Models}

In China's CRAs, the issuer-pay business model is widely adopted. It allows for bond issuers to pay the CRAs, thus unable to separate interests and failing to provide objective credit ratings to investors. In order to make more profits, credit ratings need more business and it depends on the choice of issuers, not the quality of the ratings. On the one hand, investors desire the practical credit ratings. On the other, issuers desire the ratings that meet their own needs and that tend to be higher. Therefore, the issuer-pay business models induce the collusion between issuers and CRAs, causing invalid ratings. In this business model, there is usually a chasm between credit ratings and the real quality of the bonds. Related literature also proves that the CRAs would give inflated credit ratings to the same firms in such a business model (Jiang et al., 2012; Xia, 2014). In a nutshell, the interest conflict proceeding from the issuer-pay business model makes the credit ratings inadequately predict the bond defaults, increasing the risks of defaulting.

\subsection{The Interest Conflict of Ancillary Business}

Apart from offering credit rating service, CRAs expand some auxiliary business in order to increase profits, such as consulting services, asset evaluation and risk management. Therefore, there is a conflict between credit rating service and other services in CRAs. Issuers normally would pay some ancillary services that have to do with the credit ratings for they think it might be of some help to improve their ratings or otherwise their ratings would be lower. The ancillary services to some extent inform the issuers how to design liability and risk management so as to obtain high rating scores. It also turns credit rating into a CRA auditing its own ancillary businesses to attract more customers, thus influencing the quality of credit ratings. Some scholars prove that the issuers that pay consulting services tend to have higher rating scores and they have higher default frequency compared to those with the same given rating category (Baghai \& Becker, 2018). These auxiliary services undermine the independence of CRAs 
and induce the negligence of investors' needs and trust. China's rating regulation allows the ancillary services in CRAs but forbids the consulting services during the rating process. Nevertheless, due to the close relationship between CRAs and frequent customers and the difficulty of defining the consulting services and ancillary services, the conflict of ancillary services is still a critical issue and it is one of the major reasons for massive bond defaults.

\subsection{The Interest Conflict of Public Information Ratings}

Public information ratings refer to the unsolicited credit ratings. CRAs do so to "build reputation" and offer free services as a reference for investors, and for public interest to some extent. However, there are also some downsides for public information ratings. They simply rely on public information in the market to make the ratings and due to the incomprehensive information. The ratings tend to be biased and less accurate. Some studies show that unsolicited ratings have signs of negative bias. The reason for the downgrade is that CRAs blackmail issuers by unsolicited credit rating to pay higher fees or CRAs choose to be conservative and err on the side of caution for the lack of comprehensive information (Bannier et al., 2010; Fulghieri et al., 2014). Besides, some CRAs also offer high un-commissioned ratings to attract more potential customers. Consequently, there is an interest conflict of public information ratings and have a bad impact on the quality of credit ratings. China's CRAs are still at a beginning stage and they lack adequate attention. However, with the burgeoning of the industry and marketization, the problem of the interest conflict of public information ratings is deserved to pay more attention.

\subsection{The Interest Conflict of Horizontal Competition}

Some scholars hold that the positively biased credit rating caused by the oligopoly of the US CRAs prompts the financial crisis. With CRAs suddenly downgrading the ratings, the financial crisis is even aggravated (Klein \& Leffler, 1981; Hong \& Kacperczyk, 2010). Competition seems to be the way to reduce the bias and improve the quality of the ratings. However, the fierce competition may also bring bad consequences. The market competition facilitates CRAs to cooperate with issuers to score higher to earn more business. However, it greatly reduces the quality of the ratings. CRAs in China are different from those in America, which are much smaller in number. As a consequence, the intense competition among Chinese CRAs leads to a buyer's market. This also makes most CRAs unable to obtain enough benefits, intensifying the negative effects of other interest conflicts when pursuing benefits. Hence, the quality decreases. The rating results bring some restrictions, setting a rating threshold for corporate bond issuing. In such intensive competition, CRAs often lose their independence and impartiality, leading to improper ratings. Reputation mechanisms also prove not to be a suitable way to settle the interest conflict caused by market competition in Chinese market. The vicious competition mechanism of "bad money driving 
out good" occupies a dominant position in China's credit rating market. It can be seen that in China, the horizontal interest conflict has a negative impact on the quality of credit ratings, which in turn will cause more debt defaults.

\section{Proposals}

The credit rating system aims to provide investors with reliable information that reflects the default possibility of bond issuers. In recent years, due to macro factors such as economic shifts and structural adjustments, China's bond defaults frequently occur. It exposes to some degree that there are problems in bond market. Contrast with developed countries, Chinese credit rating market and institutional environment have not developed well yet. We base on the research results of situation in China's bond market to offer some suggestions to restrain the bond defaults from the view of credit rating.

\subsection{Promoting Dual Rate System}

In China's CRAs, the issuer-pay business model is still the majority, from which interest conflict proceed. It makes CRAs lose their expected independence and impartiality. In terms of the moral dilemma for CRAs, it is suggested to turn the issuer-pay to stock exchange-pay, reducing the probability of corruption between CRAs and issuers. Investors-pay business model can also help prevent such a problem, but it requires the reputation mechanism for CRAs, which might not be suitable for still underdeveloped China's market. Consequently, the dual rate system becomes the superior, which refers to the dual ratings by two different CRAs to the same issuer. The two rating agencies can supervise each other, and the two rating results are both verified, which better improves the independence and objectivity of CRAs. It also makes the credit rating results more scientific and credible, and indirectly reduces bond defaults.

\subsection{Constructing Information Disclosure System}

The information disclosure system can improve the market transparency and standardization. When it comes to the interest conflict of ancillary business services, it is imperative to construct an information disclosure system so as to regain trust from investors. CRAs should reveal their annual reports including information like business and revenue sources. It enables the investors to better know the agency's independence and impartiality, and it also facilitates the supervision and management of the regulatory authorities. In addition, a unified information disclosure platform can also be established to facilitate investors to obtain corresponding information, which helps further enhance the authority and credibility of CRAs, improves the quality of credit ratings, and reduces the possibility of bond defaults.

\subsection{Improving the Reputation Mechanism of CRAs}

A good reputation mechanism can improve the management of CRAs. China's 
CRAs have their specific characteristics. Due to the large number of China's CRAs, the horizontal competition is extremely intense. Excessive competition greatly strengthens the interest drive, making CRAs inclined to pursue short-term benefits rather than pay attention to reputation, which has reduced the quality of credit ratings to a certain extent. Therefore, Chinese market could not simply copy the existing methods to increase horizontal competition. Instead, while ensuring the access to the credit rating industry, the reputation mechanism of rating agencies, prompting rating agencies should also be improved. CRAs need to pay attention to the accumulation of reputation capital. The influence of reputation capital can be enhanced through incentives, supervision and investors' evaluation should be considered as an important weight to promote self-discipline management in CRAs. Therefore, they would try to improve the quality of their own credit ratings, reducing the probability of bond defaults.

\subsection{Improving the Credit Rating Use System}

To improve the credit rating use system, fault liability system should be strictly performed. The current methods adopted by Chinese CRAs are still relatively backward. They should learn more from the developed foreign rating entities, and use advanced risk quantification models based on China's national conditions to establish a unified high-quality credit rating. It can reduce the impact of interest conflicts, thereby improving the accuracy of credit ratings. At the same time, corresponding supervision should be utilized to improve the quality of rating results. Relevant regulatory authorities can implement a strict fault liability system and corresponding punishment mechanisms to punish CRAs that have biased ratings and cause severe consequences. CRAs should also be urged to exercise their subjective initiative to avoid interest conflicts caused by organizational behavior, in order to enhance the authority of credit ratings, reduce biased ratings and bond defaults.

\section{Conclusion}

This paper analyzes the current situation of bond default and credit rating in China's bond market and concludes the major interest conflicts that explain why credit ratings in China cannot objectively and accurately reflect the default possibility. We hold that interest conflicts of business models, ancillary business, public information ratings and horizontal competition play a significant role in the inaccuracy of credit ratings that denote bond quality. Therefore, in order to resolve these conflicts and alleviate the problems in credit ratings and bond market, we propose four suggestions to solve these problems in the ratings and bond market, that is promoting dual rate system, constructing information disclosure system, improving the reputation mechanism of CRAs and improving the credit rating use system. This study offers novel and important insights into measures to improve the deteriorating rating quality and avoid the default problems. 


\section{Conflicts of Interest}

The authors declare no conflicts of interest regarding the publication of this paper.

\section{References}

Acharya, V. V., Bharath, S. T., \& Srinivasan, A. (2007). Does Industry-Wide Distress Affect Defaulted Firms? Evidence from Creditor Recoveries. Journal of Financial Economics, 85, 787-821. https://doi.org/10.1016/j.jfineco.2006.05.011

Baghai, R. P., \& Becker, B. (2018). Non-Rating Revenue and Conflicts of Interest. Journal of Financial Economics, 127, 94-112. https://doi.org/10.1016/j.jfineco.2017.10.004

Bannier, C. E., Behr, P., \& Güttler, A. (2010). Rating Opaque Borrowers: Why Are Unsolicited Ratings Lower? Review of Finance, 14, 263-294.

https://doi.org/10.1093/rof/rfp025

Boot, A. W., Milbourn, T. T., \& Schmeits, A. (2006). Credit Ratings as Coordination Mechanisms. The Review of Financial Studies, 19, 81-118.

https://doi.org/10.1093/rfs/hhj009

Bosch, O., \& Steffen, S. (2011). On Syndicate Composition, Corporate Structure and the Certification Effect of Credit Ratings. Journal of Banking \& Finance, 35, 290-299. https://doi.org/10.1016/j.jbankfin.2010.08.002

Cornaggia, J., Cornaggia, K. J., \& Xia, H. (2016). Revolving Doors on Wall Street. Journal of Financial Economics, 120, 400-419. https://doi.org/10.1016/j.jfineco.2016.01.007

Finnerty, J. D., Miller, C. D., \& Chen, R. R. (2013). The Impact of Credit Rating Announcements on Credit Default Swap Spreads. Journal of Banking \& Finance, 37, 2011-2030. https://doi.org/10.1016/j.jbankfin.2013.01.028

Fulghieri, P., Strobl, G., \& Xia, H. (2014). The Economics of Solicited and Unsolicited Credit Ratings. The Review of Financial Studies, 27, 484-518.

https://doi.org/10.1093/rfs/hht072

Ghosh, A., \& Moon, D. (2005). Auditor Tenure and Perceptions of Audit Quality. The Accounting Review, 80, 585-612. https://doi.org/10.2308/accr.2005.80.2.585

Giesecke, K., Longstaff, F. A., Schaefer, S., \& Strebulaev, I. (2011). Corporate Bond Default Risk: A 150-Year Perspective. Journal of Financial Economics, 102, 233-250. https://doi.org/10.1016/j.jfineco.2011.01.011

Hong, H., \& Kacperczyk, M. (2010). Competition and Bias. The Quarterly Journal of Economics, 125, 1683-1725. https://doi.org/10.1162/qjec.2010.125.4.1683

Hu, X., Huang, H., Pan, Z., \& Shi, J. (2019). Information Asymmetry and Credit Rating: A Quasi-Natural Experiment from China. Journal of Banking \& Finance, 106, 132-152. https://doi.org/10.1016/j.jbankfin.2019.06.003

Jiang, J. X., Stanford, M. H., \& Xie, Y. (2012). Does It Matter Who Pays for Bond Ratings? Historical Evidence. Journal of Financial Economics, 105, 607-621. https://doi.org/10.1016/j.jfineco.2012.04.001

Kisgen, D. J. (2006). Credit Ratings and Capital Structure. The Journal of Finance, 61, 1035-1072. https://doi.org/10.1111/j.1540-6261.2006.00866.x

Klein, B., \& Leffler, K. B. (1981). The Role of Market Forces in Assuring Contractual Performance. Journal of political Economy, 89, 615-641. https://doi.org/10.1086/260996

Kuehn, L. A., \& Schmid, L. (2014). Investment-Based Corporate Bond Pricing. The Journal of Finance, 69, 2741-2776. https://doi.org/10.1111/jofi.12204 
Li, J., Shin, Y. S., \& Moore, W. T. (2006). Reactions of Japanese Markets to Changes in Credit Ratings by Global and Local Agencies. Journal of Banking \& Finance, 30, 1007-1021. https://doi.org/10.1016/j.jbankfin.2005.05.026

Livingston, M., Poon, W. P., \& Zhou, L. (2018). Are Chinese Credit Ratings Relevant? A Study of the Chinese Bond Market and Credit Rating Industry. Journal of Banking \& Finance, 87, 216-232. https://doi.org/10.1016/j.jbankfin.2017.09.020

Ma, R., \& Shi, X. (2016). Do the Credit Ratings in China's Bond Market Have the Riskiness-Discrimination Power: An Earnings Management Perspective. China Economic Quarterly, 15, 197-216. (In Chinese)

Millon, M. H., \& Thakor, A. V. (1985). Moral Hazard and Information Sharing: A Model of Financial Information Gathering Agencies. The Journal of Finance, 40, 1403-1422. https://doi.org/10.1111/j.1540-6261.1985.tb02391.x

Poon, W. P., \& Chan, K. C. (2008). An Empirical Examination of the Informational Content of Credit Ratings in China. Journal of Business Research, 61, 790-797. https://doi.org/10.1016/j.jbusres.2007.08.001

Stolper, A. (2009). Regulation of Credit Rating Agencies. Journal of Banking \& Finance, 33, 1266-1273. https://doi.org/10.1016/j.jbankfin.2009.01.004

Sufi, A. (2007). Information Asymmetry and Financing Arrangements: Evidence from Syndicated Loans. The Journal of Finance, 62, 629-668. https://doi.org/10.1111/j.1540-6261.2007.01219.x

Wang, B., Lyu, Y., \& Ye, Y. (2016). Pricing the Risk of Implicit Government Guarantee: Evidence from Chinese Corporate Bond Market. Economic Research Journal, 51, 155-167. (In Chinese)

Xia, H. (2014). Can Investor-Paid Credit Rating Agencies Improve the Information Quality of Issuer-Paid Rating Agencies? Journal of Financial Economics, 111, 450-468. https://doi.org/10.1016/j.jfineco.2013.10.015 